\title{
Section 1983 in State Court: A Remedy for Unconstitutional State Taxation
}

\author{
William L. Taylor†
}

Victims of federally unconstitutional state taxation are currently without adequate means to vindicate their federal rights. ${ }^{1}$ State-provided remedies do not furnish these victims with sufficient incentive to challenge the constitutionality of such taxation. ${ }^{2}$ Given that unconstitutional taxation is a deprivation of federal rights under color of state law, and thus within the ambit of 42 U.S.C. $\S 1983,{ }^{3}$ the remedies available under that section, including attorney's fees for successful claimants, could fill the void left by the inadequacy of state remedies. The traditional fora for section 1983 claims, the federal district courts, are not available for state tax section 1983 actions, however, because federal law prohibits these courts from interfering with state taxation. ${ }^{4}$ Thus, taxpayers must take their section 1983 claims to state courts. Notwithstanding their obligation to entertain section 1983 actions generally, ${ }^{5}$ most state courts have refused to entertain state tax section 1983 claims. $^{\circ}$ As a consequence, the federal constitutional rights of state taxpayers are not adequately protected.

This Note argues that this result is unacceptable. Part I demonstrates that a meaningful state tax section 1983 cause of action in state court is

$\dagger$ The author would like to express his appreciation to Lea Brilmayer and Henry L. Parr, Jr. for their helpful comments, and to G. Waitman Taylor, Jr. for reasons so numerous and involved that they are beyond the scope of this Note.

1. This Note analyzes state taxation that violates the U.S. Constitution. That the taxation may also violate state constitutional provisions does not affect this analysis.

2. See infra text accompanying notes 8-10.

3. 42 U.S.C. $\S 1983$ was originally enacted as $\S 1$ of the Civil Rights Act of 1871 , ch. 22,17 Stat. 13, 13. Section 1983 provides in pertinent part:

Every person who, under color of any statute, ordinance, regulation, custom, or usage, of any State or Territory or the District of Columbia, subjects, or causes to be subjected, any citizen of the United States or other person within the jurisdiction thereof to the deprivation of any rights, privileges, or immunities secured by the Constitution and laws, shall be liable to the party injured in an action at law, suit in equity, or other proper proceeding for redress. 42 U.S.C. $\S 1983$ (1982).

In the landmark case of Monroe v. Pape, 365 U.S. 167 (1961), the Supreme Court extended the civil rights remedies under $\$ 1983$ beyond the context of racial discrimination to other violations of the Constitution. Section 1983 now provides a federal cause of action to "taxpayers, or anyone else who [is] able to prove that his constitutional or federal rights [have] been denied by any State." Fair Assessment in Real Estate Ass'n v. McNary, 454 U.S. 100, 103-04 (1981).

4. The broad policy of federal court noninterference with state taxation prevents federal district courts from entertaining challenges to state taxation. See infra text accompanying notes 14-34.

5. See infra text accompanying notes 52-74.

6. See infra note 79 . 
necessary to ensure the protection of the federal rights of state taxpayers. ${ }^{7}$ Part II argues that state courts must entertain section 1983 actions generally, and Part III concludes that these courts are required to hear state tax section 1983 actions as well.

\section{The Need for a State Tax Section 1983 Gause of Action in STate Court}

The remedies provided under section 1983 are essential if the victims of unconstitutional taxation are to obtain redress. Because federal courts are not open to taxpayers with section 1983 actions, state courts must stand ready to entertain these claims.

\section{A. The Deficiency of State Remedies}

All states have remedies available to taxpayers who successfully challenge the federal constitutionality of state tax laws or procedures. ${ }^{8}$ The problem with many of these state remedies, however, is that they do not provide taxpayers with sufficient incentive to vindicate their federal rights. In particular, most states do not allow taxpayers who successfully challenge state taxation to recover attorney's fees. ${ }^{\theta}$ As a result, a state is left

7. The analysis of this Note is directed both at unconstitutional statutes and at unconstitutional assessment practices and procedures. Although courts, especially federal courts, appear to be reluctant to embroil themselves in tax assessment disputes, see, e.g., McNary, 454 U.S. at $107 \mathrm{n.4}$, taxpayers challenging unconstitutional tax assessment practices may be in need of greater protection than taxpayers challenging the constitutionality of a state tax statute. A single vindictive tax assessor has the power to tax unconstitutionally by, for example, assessing the property of members of a particular political party at double the normal rate. An unconstitutional statute, on the other hand, must be approved by an entire legislative body and usually by the state's executive branch as well. Because those subject to the caprice of a tax assessor have fewer checks on the source of the unconstitutional taxation, they arguably have a greater need for effective means to protect their rights.

8. See, e.g., Ky. Rev. Stat. ANN. $\$ 133.120$ (Bobbs-Merrill Supp. 1984) (providing appeal from tax assessments); KY. REv. STAT. ANN. § 134.590 (Bobbs-Merrill 1982) (providing for refund of "taxes held unconstitutional"); Mo. ANN. STAT. § 139.031 (Vernon Supp. 1985) (providing action for recovery of taxes paid under protest); S.C. CoDE ANN. \$ 12-47-220 (Law. Co-op 1976) (same). Indeed, even if a state did not have a statutory remedy for unconstitutional taxation, the taxpayer would have a remedy directly under the Fourteenth Amendment. See, e.g., Ward v. Board of County Comm'rs, 253 U.S. 17, 24 (1920) (taxpayers allowed to recover unconstitutionally collected taxes notwithstanding that no statutory cause of action had been provided by state); $c f$. General Oil Co. v. Crain, 209 U.S. 211 (1908) (taxpayer must have remedy for unconstitutional state taxation)

9. See, e.g., Ky. Rev. Stat. ANN. \$§ 133.120, 134.590; Holsclaw v. Stephens, 507 S.W.2d 462 480 (Ky. 1974) ("Kentucky follows the general rule which does not permit the allowance of attorneys' fees in the absence of a statute or contract expressly providing therefor."); Mo. ANN. STAT. \$ 139.031; Mayor of Liberty v. Beard, 636 S.W.2d 330, 331 (Mo. 1982) (en banc) (per curiam) ("The rule in Missouri is that absent statutory authorization or contractual agreement, each litigant, with few exceptions, must bear the expense of his own attorneys' fees . . . ."); S.C. CoDE ANN. § 1247-270 (Law. Co-op. 1976) (limiting costs in actions to recover taxes paid under protest); Hegler v. Gulf Ins. Co., 270 S.C. 548, 549, 243 S.E.2d 443, 444 (1978) ("As a general rule, attorney's fees are not recoverable [in South Carolina] unless authorized by contract or statute."); see also State Tax Comm'n v. Fondren, 387 So. 2d 712 (Miss. 1980) (en banc) (taxpayers unable to collect attorney's fees under state statutes), cert. denied, 450 U.S. 1040 (1981). 
free to extract small sums unconstitutionally from its taxpayers. For example, a state could enact a statute under which all resident aliens would be taxed an additional $\$ 1.00$ per year, or a single malicious tax assessor could slightly overassess the property of nonresidents of the state. As a purely economic matter, these taxpayers would be better off paying the unconstitutional tax than incurring the legal fees necessary to challenge the tax. ${ }^{10}$

Section 1983 offers an alternative to inadequate state remedies. Congress enacted section 1983 to provide a civil remedy for deprivations of federal rights under color of state law, such as unconstitutional taxation. To further the goals of section 1983, Congress passed the Civil Rights Attorney's Fees Awards Act of 1976 ("section 1988"), 11 which provides for the recovery of attorney's fees by successful plaintiffs in a number of actions including those under section $1983 .{ }^{12}$ Because the monetary dam-

10. The facts of a recent case, Spencer v. South Carolina Tax Comm'n, 281 S.C. 492, 316 S.E.2d 386 (1984), affd by an equally divided Court, 105 S. Ct. 1859 (1985) (per curiam), serve to illustrate the problem. The Spencers, residents of North Carolina, earned all of their income in South Carolina and were subject to South Carolina income tax provisions. South Carolina had a statute which denied non-residents certain deductions and therefore taxed these individuals more heavily than otherwise similar South Carolina residents. The amount of the tax illegally imposed on the Spencers was under $\$ 600.00$, substantially less than the expense necessary to challenge the constitutionality of the statute. Although the statute was patently unconstitutional, the unavailability of attorney's fees reduced the Spencers' incentive to challenge the statute. In addition, because the Spencers were not residents of South Carolina and were therefore ineligible to vote in South Carolina elections, they had no opportunity to effect a change in the statute through the political process.

11. Pub. L. No. 94-559, 90 Stat. 2641 (1976) (codified at 42 U.S.G. $\S 1988$ (1982)). Section 1988 provides in pertinent part:

In any action or proceeding to enforce a provision of sections $1981,1982,1983,1985$, and

1986 of this title . . . the court, in its discretion, may allow the prevailing party, other than

the United States, a reasonable attorney's fee as part of the costs.

12. Congress enacted $\S 1988$ to provide an exception in civil rights cases to the "American rule" which, as interpreted by the Supreme Court in Alyeska Pipeline Serv. Co. v. Wilderness Soc'y, 421 U.S. 240 (1975), would not allow a successful plaintiff in a civil rights action to recover attorney's fees. See S. ReP. No. 1011, 94th Cong., 2d Sess. 4, reprinted in 1976 U.S. Code Cong. \& AD. News 5908, 5911-12. Section 1988 applies to actions under $\S 1983$ whether they are brought in federal or state court. See Maine v. Thiboutot, 448 U.S. 1, 10-11 (1980). A successful plaintiff may recover attorney's fees under $\S 1988$ even if the court does not reach the plaintiff's $\S 1983$ action, if the $\S 1983$ claim is substantial and if the state law claim on which the plaintiff prevailed and the $\S$ 1983 claim both arise out of a common nucleus of operative facts. See Maher v. Gagne, 448 U.S. 122, 132 n.15 (1980); see also Stratos v. Department of Pub. Welfare, 387 Mass. 312, 316-20, 439 N.E.2d $778,782-85$ (1982) (granting attorney's fees under $\S 1988$ even though court did not reach plaintiff's $\$ 1983$ claim because he had prevailed on his state law claim). Although $\S 1988$ gives courts discretion in awarding attorney's fees, this discretion is quite limited. Congress stated that a prevailing plaintiff "'should ordinarily recover an attorney's fee unless special circumstances would render such an award unjust." "See S. REP. No. 1011, 94th Cong., 2d Sess. 4, reprinted in 1976 U.S. Code Cong. \& AD. News 5908, 5912 (quoting Newman v. Piggie Park Enters., 390 U.S. 400, 402 (1968) (per curiam)); see also Johnson v. Blum, 58 N.Y.2d 454, 457-59, 448 N.E.2d 449, 450-51, 461 N.Y.S.2d 782, 783-84 (1983) (per curiam) (attorney's fees must be awarded absent "special circumstances").

In the debates over $\$ 1988$, Congress noted the importance of attorney's fees in ensuring the protection of federal rights. See 122 Cong. REc. 35,128 (1976) (remarks of Rep. Seiberling) ("In fact, a failure to authorize the awarding of attorneys' fees in civil rights cases will, as a practical matter, repeal the civil rights laws for most Americans."); id. at 35,127 (remarks of Rep. Holtzman) ("[Section 1988] will help to assure that all Americans can have access to the courts to obtain the protections 
age resulting from unconstitutional taxation may not be large enough to make it worthwhile for an individual taxpayer to incur the legal fees necessary to challenge the tax, the availability of attorney's fees can make the difference between protecting the federal rights of taxpayers and allowing violations to go unredressed. ${ }^{13}$

\section{B. The Unavailability of Federal Courts for State Tax Section 1983 Claims}

Taxpayer challenges to unconstitutional state taxation, even those challenges brought pursuant to section 1983, are not actionable in federal court. ${ }^{14}$ Federal courts are precluded from entertaining state tax section 1983 claims by a long-standing policy of federal judicial noninterference with state taxation. This policy is embodied in the Tax Injunction Act, ${ }^{16}$ the Eleventh Amendment, ${ }^{16}$ and the principle of comity as articulated by the Supreme Court in Fair Assessment in Real Estate Association v. McNary. ${ }^{17}$

The Tax Injunction Act bars federal courts from granting prospective relief-either injunctive or declaratory ${ }^{18}$ - from unconstitutional state taxation. ${ }^{19}$ The Act prohibits federal district courts from restraining a state in its taxing power if a "plain, speedy and efficient remedy" is available in

against discrimination contained in our laws and the Constitution."); see also Thiboutot, 448 U.S. at 11 (noting importance of $\S 1988$ to $\S 1983$ claimants).

13. The Senate Report on the Attorney's Fees Awards Act of 1976 noted: "If our civil rights laws are not to become mere hollow pronouncements which the average citizen cannot enforce, we must maintain the traditionally effective remedy of fee shifting in these cases." S. REP. No. 1011, 94th Cong., 2d Sess. 6, reprinted in 1976 U.S. Code Cong. \& AD. News 5908, 5913 (emphasis added). The lower South Carolina court in Spencer v. South Carolina Tax Comm'n upheld the Spencers' challenge to the constitutionality of the tax statute, but refused to entertain their $\$ 1983$ claim and thercfore denied their request for attorney's fees. No. 81-CP-23-3844 (S.C.C.P. Oct. 29, 1982). It is interesting that the court characterized the Spencers' success as a "hollow victory." Id. at 3.

14. See Pennhurst State School \& Hosp. v. Halderman, 465 U.S. 89, 122 (1984) ("Challenges to the validity of state tax systems under 42 U.S.C. $\$ 1983$. . must be brought in state court.") (citing Fair Assessment in Real Estate Ass'n v. McNary, 454 U.S. 100 (1981)).

15. Pub. L. No. 75-332, 50 Stat. 738 (1937) (codified as amended at 28 U.S.C. $§ 1341$ (1982)). Section 1341 provides:

The district courts shall not enjoin, suspend or restrain the assessment, levy or collection of any tax under State law where a plain, speedy and efficient remedy may be had in the courts of such State.

16. The Eleventh Amendment provides:

The Judicial power of the United States shall not be construed to extend to any suit in law or equity, commenced or prosecuted against one of the United States by Gitizens of another State, or by Citizens or Subjects of any Foreign State.

U.S. ConST, amend. XI.

17. 454 U.S. 100 (1981).

18. Although the Tax Injunction Act on its face restrains federal district courts only from granting injunctions, the Supreme Court has held that it also prevents those courts from granting declaratory relief. See California v. Grace Brethren Church, 457 U.S. 393, 408 (1982).

19. For a general discussion of the Tax Injunction Act, see Note, The Tax Injunction Act and Suits for Monetary Relief, 46 U. CHI. L. REv. 736 (1979). 
state court. ${ }^{20}$ That the taxpayer is seeking relief under section 1983 is irrelevant. ${ }^{21}$ Moreover, the prohibition applies whether the action is instituted against the state directly or against a state official in either her individual or official capacity. ${ }^{22}$

Just as the Tax Injunction Act prevents federal courts from granting equitable relief from unconstitutional taxation, the Eleventh Amendment prohibits these courts from granting relief in the form of money damages from such taxation. The Eleventh Amendment bars federal district courts from entertaining actions seeking retroactive relief against a state. ${ }^{23} \mathrm{Al}$ though Congress has the authority under section 5 of the Fourteenth Amendment to override the Eleventh Amendment, ${ }^{24}$ the Supreme Court has held that Congress did not exercise that authority when it enacted section 1983. ${ }^{25}$ Thus, the Eleventh Amendment prevents a taxpayer from asserting a section 1983 damages action in federal court against a state. Like other section 1983 claimants, taxpayers cannot circumvent the prohibitions of the Eleventh Amendment by bringing suit against the appropriate state official (i.e., the state treasurer) in her official capacity, because federal court damage suits against state officials in their official capacity are deemed to be suits against the state, ${ }^{26}$ and are therefore not actionable in federal court without the state's consent.

A taxpayer is also prohibited from suing a state tax official in her individual capacity for damages in federal district court. ${ }^{27}$ In Fair Assessment in Real Estate Association v. McNary, ${ }^{28}$ the Supreme Court held that a

20. Some commentators have suggested that the phrase "plain, speedy and efficient" is synonomous with "adequate." See, e.g., P. Bator, P. Mishinin, D. Shapiro \& H. Wechsler, Hart and Wechsler's The Federal Courts and the Federal. System 979 (2d ed. 1973). For a discussion of whether the state court remedy is "plain, speedy and efficient" if it does not provide a taxpayer with the remedies available under $\$ 1983$, see infra note 33 .

21. See, e.g., Rosewell v. LaSalle Nat'l Bank, 450 U.S. 503 (1981) (taxpayer's $§ 1983$ claim in federal court held improper because state offered plain, speedy and efficient remedy).

22. The Tax Injunction Act may not be circumvented by resorting to the fiction used in Ex parte Young, 209 U.S. 123 (1908) (allowing equitable action against state official notwithstanding that such suit could not be maintained against state directly), to challenge state taxation in federal court. See, e.g., Rosewell, 450 U.S. 503.

23. Although the text of the Eleventh Amendment does not address suits against a state by its own citizens, the Supreme Court has ruled that the Eleventh Amendment's proscription encompasses such suits. See Hans v. Louisiana, 134 U.S. 1 (1890).

24. See Fitzpatrick v. Bitzer, 427 U.S. 445 (1976).

25. See Quern v. Jordan, 440 U.S. 332 (1979).

26. See Ford Motor Co. v. Department of Treasury, 323 U.S. 459 (1945) (suit to recover money against state department of treasury held to be suit against state); Smith v. Reeves, 178 U.S. 436 (1900) (suit against state treasurer in his official capacity held to be suit against state). See generally Note, Jurisdiction to Enforce Federal Statutes Regulating State Taxation: The Eleventh Amendment-Section 1341 Imbroglio, 70 Yale L.J. 636 (1961) (discussing Eleventh Amendment and Tax Injunction Act as bars tó federal court actions challenging state taxation).

27. For a discussion of whether a state tax $\S 1983$ suit should properly be brought against an official in her individual or official capacity, see infra text accompanying notes 98-102.

28. 454 U.S. 100 (1981). 
taxpayer challenging the constitutionality of a state tax official's conduct may not maintain an individual-capacity section 1983 damages action in federal court. ${ }^{29}$ The McNary Court stated that a suit against a state tax official would have a chilling effect on that official's performance of her duties, and would therefore disrupt the state's tax collection efforts. ${ }^{30} \mathrm{Re}$ lying on the principle of comity, ${ }^{31}$ the Court held that a federal district court should refuse jurisdiction over such a taxpayer suit if "a plain, adequate, and complete remedy"32 is available to the taxpayer under state law. ${ }^{33}$ The McNary Court repeatedly noted that the federal district courts should avoid interfering with state taxation whenever possible. ${ }^{34}$

Given that federal courts cannot entertain state tax section 1983 claims and that the remedies under that section are needed to ensure the protection of taxpayers' rights, the assured availability of state courts as fora for these claims is of paramount importance. Part II will assess the obligation

\section{Id. at 113-14.}

30. Id. at 115 .

31. The McNary Court did not decide whether the action was also barred by the Tax Injunction Act. Id. at 107.

32. The Court could "discern no significant difference . . . between remedies which are 'plain, adequate, and complete' . . . and those which are 'plain, speedy and efficient,' within the meaning of the [Tax Injunction Act]." Id. at 116 n.8.

33. Id. at 116. Thus, the McNary decision clearly leaves the federal courts open to one specific class of state tax claims: those brought where a "plain, adequate, and complete" remedy is not available under state law. Similarly, the Tax Injunction Act leaves the federal courts open if the taxpayer does not have a "plain, speedy and efficient" remedy in state court. See supra note 15. Left undecided is whether the taxpayer's "adequate" remedies must include those available under $\S 11983$ and 1988. If the state court must provide these remedies, then a taxpayer in a state whose courts refuse to entertain $\$ 1983$ claims may assert his claim in federal court.

At least one circuit, however, has held that even after a state court has refused to hear a taxpayer's $\S 1983$ claim, the taxpayer cannot assert that claim in federal court. See Redd v. Lambert, 674 F.2d 1032 (5th Cir. 1982). Moreover, even if such a claim were allowed in federal court, other reasons support a requirement that state courts entertain state tax $\S 1983$ actions. First, a federal court could hear the taxpayer's $\S 1983$ claim only after a state court had refused to entertain it. Thus, to have a $\S$ 1983 claim adjudicated, a taxpayer would have to incur the costs of litigating his claim in both state and federal court. The uncertainty of recovery in this time-consuming and expensive process might deter risk-averse taxpayers from asserting meritorious claims. Although subsequent taxpayers in a given state might be allowed to proceed directly to federal court if the appropriate state courts had refused to hear previous state tax $\S 1983$ claims, it is conceivable that each taxpayer would have to be turned away by the state courts before he would be allowed to proceed in federal court. Moreover, due to geographic, time, and financial constraints, the state court may for all practical purposes be the only forum available to many $\$ 1983$ claimants. See infra notes 76-77 and accompanying text.

34. See 454 U.S. at 102, 108, 111. McNary, which involved a tax assessment challenge, specifically left open the question whether comity also bars a federal district court from entertaining a facial attack on a tax statute. Id. at 107 n.4. This question, however, seems moot. Such a facial attack is barred, if not by the principle of comity, then certainly by the Eleventh Amendment and the Tax Injunction Act. See supra notes 18-26 and accompanying text. The only action not foreclosed is a suit by a taxpayer against a state tax official in her individual capacity, seeking damages to remedy that official's enforcement of an unconstitutional state tax statute. Unless enforcement of the statute in question violated a clearly established constitutional right, however, the official would be immune from such a suit. See Harlow v. Fitzgerald, 457 U.S. 800, 818 (1982); see also Pierson v. Ray, 386 U.S. 547, 557 (1967) (official "not charged with predicting the future course of constitutional law"). 
of state courts to entertain section 1983 claims generally, and Part III will focus on state tax section 1983 claims specifically.

\section{The Role of State Gourts in the Enforcement of Section 1983 Claims in General}

In Martinez v. California, ${ }^{36}$ the Supreme Court ruled that state courts possess concurrent jurisdiction over claims brought under section $1983 .^{36}$ The Court has, however, left open the question whether state courts are required to entertain these claims. ${ }^{37}$ Most state courts have freely accepted jurisdiction over section 1983 and have entertained claims brought under that section. ${ }^{38}$ Several states have even recognized an obligation on the

35. 444 U.S. 277 (1980).

36. Id. at 283 n.7 ("We note that the California courts accepted jurisdiction of this [\$ 1983] claim. That exercise of jurisdiction appears to be consistent with the general rule [of Testa v. Katt, 330 U.S. 386, 391 (1947)]."). The Court reaffirmed the Martinez holding in Maine v. Thiboutot, 448 U.S. 1, 3 n.1 (1980) ("Any doubt that state courts may also entertain [ $\S 1983$ ] actions was dispelled by Martinez . . . There, while reserving the question whether state courts are obligated to entertain $\S 1983$ actions, we held that Congress has not barred them from doing so.") (emphasis in original). For a discussion of the evolution of $\$ 1983$ and its jurisdictional provision, see Note, The Enforceability and Proper Implementation of $\$ 1983$ and the Attorney's Fees Awards Act in State Courts, 20 ARIZ. L. REv. 743, 746-53 (1978).

37. See Martinez, 444 U.S. at 283 n.7 ("We have never considered, however, the question whether a State must entertain a claim under $\$ 1983 . ")$ (emphasis in original); see also Thiboutot, 448 U.S. at 3 n.1 (noting that Martinez Court had reserved question whether state courts must entertain $\S 1983$ actions).

38. Terrell v. City of Bessemer, 406 So. 2d 337, 340 (Ala. 1981); Fairbanks Correctional Center Inmates v. Williamson, 600 P.2d 743, 747 (Alaska 1979); New Times, Inc. v. Arizona Bd. of Regents, 110 Ariz. 367, 374, 519 P.2d 169, 176 (1974) (en banc); Burden v. Hayden, 275 Ark. 93, 96, 627 S.W.2d 555, 557 (1982); Brown v. Pitchess, 13 Cal. 3d 518, 521-23, 531 P.2d 772, 774-75, 119 Cal. Rptr. 204, 206-07 (1975) (en banc); Espinoza v. O'Dell, 633 P.2d 455, 460 n.2 (Colo. 1981) (en banc), cert. dismissed, 456 U.S. 430 (1982); Vason v. Carrano, 31 Conn. Supp. 338, 338, 330 A.2d 98, 98-99 (Super. Ct. 1974); Slawik v. State, 480 A.2d 636, 640 (Del. 1984); Long v. District of Columbia, 469 F.2d 927, 937 (D.C. Cir. 1972); Davis v. City of Roswell, 250 Ga. 8, 9, 295 S.E.2d 317, 318-19 (1982); Alberty v. Daniel, 25 Ill. App. 3d 291, 294-95, 323 N.E.2d 110, 113-14 (1974); Colvin v. Bowen, 399 N.E.2d 835, 837-38 (Ind. Ct. App. 1980); Blessum v. Howard County Bd. of Supervisors, 295 N.W.2d 836, 844 (Iowa 1980); Cooper v. Hutchinson Police Dep't, 6 Kan. App. 2d 806, 807-08, 636 P.2d 184, 185-86 (1981); Scott v. Campbell County Bd. of Educ., 618 S.W.2d 589, 590 (Ky. 1981); Ricard v. State, 390 So. 2d 882, 883-84 (La. 1980); Thiboutot v. State, 405 A.2d 230, 235 (Me. 1979), aff d sub nom. Maine v. Thiboutot, 448 U.S. 1 (1980); De Bleecker v. Montgomery County, 48 Md. App. 455, 459, 427 A.2d 1075, 1077 (1981), rev'd on other grounds, 292 Md. 498, 438 A.2d 1348 (1982); Santana v. Registrars of Voters, 384 Mass. 487, 492, 425 N.E.2d 745, 749 (1981); Dickerson v. Warden, Marquette Prison, 99 Mich. App. 630, 634, 298 N.W.2d 841, 843 (1980); Sweeney v. Special School Dist. No. 1, 368 N.W.2d 288, 291-92 (Minn. Ct. App. 1985); Shapiro v. Columbia Union Nat'l Bank \& Trust Co., 576 S.W.2d 310, 315-16 (Mo. 1978) (en banc), cert. denied, 444 U.S. 831 (1979); MBG, Inc. v. Engel, 119 N.H. 8, 10, 397 A.2d 636, 637 (1979); Endress v. Brookdale Community College, 144 N.J. Super. 109, 132, 364 A.2d 1080, 1092 (1976); Gomez v. Board of Educ., 85 N.M. 708, 710-11, 516 P.2d 679, 681-82 (1973); Felder v. Foster, 107 Misc. 2d 782, 783-84, 436 N.Y.S.2d 675, 677 (Sup. Ct. 1981); Kristensen v. Strinden, 343 N.W.2d 67, 69-71 (N.D. 1983); Jackson v. Kurtz, 65 Ohio App. 2d 152, 156-57, 416 N.E.2d 1064, 1067 (1979); Powell v. Seay, 553 P.2d 161, 164 (Okla. 1976); Rosacker v. Multnomah County, 43 Or. App. 583, 587, 603 P.2d 1216, 1218 (1979); Commonwealth ex rel. Saunders v. Creamer, 464 Pa. 2, 4 n.3, 345 A.2d 702, 703 n.3 (1975); Carvalho v. Coletta, 457 A.2d 614, 617 (R.I. 1983); Beauregard v. City of St. Albans, 141 Vt. 624, 626-27, 450 A.2d 1148, 1149 (1982); Kuehn v. Renton School Dist. No. 403, 103 Wash. 2d 594, 597-98, 694 P.2d 1078, 1080 (1985) (en banc); Harrah v. Lever- 
part of courts in their state to entertain such actions. ${ }^{39} \mathrm{~A}$ minority of state courts, however, have refused to entertain section 1983 claims. ${ }^{40}$ This Note argues that these refusals are based on a misconception of the role of state courts in the federal scheme and are therefore improper. State courts must entertain federal causes of action over which they have jurisdiction, and section 1983 actions are no exception to this rule.

\section{A. The Obligation of State Courts to Entertain Federal Causes of Action}

The obligation of state courts to entertain federal causes of action is well established. In Testa $v$. Katt, ${ }^{41}$ the Supreme Court broadly ruled that a state court generally is not free to deny the enforcement of a valid federal claim if that court has "jurisdiction adequate and appropriate under

ette, 271 S.E.2d 322, 332 (W. Va. 1980); Terry v. Kolski, 78 Wis. 2d 475, 496-97, 254 N.W.2d 704, 712 (1977); Board of Trustees v. Holso, 584 P.2d 1009, 1017 (Wyo. 1978).

39. See Terrell v. City of Bessemer, 406 So. 2d at 340 ("[C]ourts of this state must accept jurisdiction over claims brought under 42 U.S.C. $\S 1983$, if a $\S 1983$ plaintiff selects a state court as his forum."); Brown v. Pitchess, 13 Cal. 3d at 523, 531 P.2d at 775, 119 Cal. Rptr. at 207 (In $\$ 1983$ cases " the existence of [concurrent] jurisdiction creates the duty to exercise it." ") (quoting Gerry of Cal. v. Superior Court, 32 Cal. 2d 119, 122, 194 P.2d 689, 692 (1948)); Colvin v. Bowen, 399 N.E.2d at 837 ("[S]tate courts of general jurisdiction are not free to deny enforcement of claims growing out of a valid federal statute such as \$ 1983."); Felder v. Foster, 107 Misc. 2d at 783-84, 436 N.Y.S.2d at 677 ("This court has jurisdiction to entertain all proceedings brought under sections 1983 and $1988 \ldots$ and must exercise that jurisdiction when such a proceeding is properly before it ....") (citations omitted); Terry v. Kolski, 78 Wis. 2d at 496-97, 254 N.W.2d at 712 ("[C]ourts of this state have jurisdiction to hear and decide sec. 1983 cases. In addition, they have an affirmative obligation under the Constitution of the United States to take jurisdiction . . . .").

40. See City of North Miami v. Schy, 408 So. 2d 670, 670 (Fla. Dist. Ct. App. 1981) (because U.S. Supreme Court has not held that state courts must entertain $\S 1983$ actions, lower state court could refuse to hear such claim); Backus v. Chilivis, $236 \mathrm{Ga} .500,505,224$ S.E.2d 370, 374 (1976) (taxpayer may not circumvent established state procedures for equalizing tax assessments by asserting $\S 1983$ claim); State Tax Comm'n v. Fondren, 387 So. 2d 712, 723 (Miss. 1980) (en banc) (because state tax $\$ 1983$ claim may not be litigated in federal court, it likewise may not be litigated in state court), cert. denied, 450 U.S. 1040 (1981); Stufflebaum v. Panethiere, 691 S.W.2d 271, 272 (Mo. 1985) (en banc) (state tax $\$ 1983$ claim held improper because state law provided plain, adequate, and complete remedy); Strain v. Baryla, No. TSB-H-84(44)S (N.Y. State Tax Comm'n June 1, 1984) (available on LEXIS, States library, NYtax file) (Tax Injunction Act bars courts, including state courts, from entertaining $\S 1983$ claims challenging state taxation); Johnston v. Gaston County, 71 N.C. App. 707, 712-13, 323 S.E.2d 381, 384 (1984) (state tax $\S 1983$ claim held improper because state law provided plain, adequate, and complete remedy), review denied, 313 N.C. 508, 329 S.E.2d 392 (1985); Spencer v. South Carolina Tax Comm'n, 281 S.C. 492, 497, 316 S.E.2d 386, 388-89 (1984) (taxpayer may not circumvent state remedies by invoking $\S 1983$ ), affd by an equally divided Court, 105 S. Ct. 1859 (1985) (per curiam); Chamberlain v. Brown, 223 Tenn. 25, 31-35, 442 S.W.2d 248, 250-52 (1969) (arguing that it would be illogical for state courts to entertain $\S 1983$ claims).

In several of these cases, the $\$ 1983$ claimant was challenging allegedly unconstitutional state taxation. For a discussion of the propriety of state court refusals to entertain state tax $\$ 1983$ claims, see infra notes 79-113 and accompanying text.

41. 330 U.S. 386 (1947). Testa involved a Rhode Island court's refusal to entertain an action brought under the federal Emergency Price Control Act. The refusal was premised on the belief that the Act was a penal law, and that the courts of Rhode Island were not obligated to enforce the penal laws of another sovereign. 
established local law" to adjudicate similar actions. ${ }^{42}$ The Court stated that the assumption that state courts do not have to entertain federal causes of action "flies in the face of the fact that the States of the Union constitute a nation [and] disregards the purpose and effect of [the supremacy clause of the United States Constitution]."13

Two earlier Supreme Court decisions requiring state courts to entertain actions under the Federal Employers Liability Act foreshadowed the Testa holding.4 The Court in Mondou v. New York, New Haven 8 Hartford Railroad, ${ }^{45}$ dismissed as "quite inadmissible" the contention that a state court could refuse to entertain a federal cause of action if the federal law in question conflicted with the policy of the state. ${ }^{46}$ The Court held that Congress, acting under the supremacy clause, had preempted any conflicting state policy. ${ }^{47}$ In addressing the assertion that enforcing federal causes of action would unduly burden state courts, the Court noted that " $[w]$ e are not disposed to believe that the exercise of jurisdiction by the state courts will be attended by any appreciable inconvenience or con-

42. Id. at 394 .

43. Id. at 389. The supremacy clause provides in pertinent part:

This Constitution, and the Laws of the United States which shall be made in pursuance thereof ... shall be the supreme Law of the Land; and the Judges in every State shall be bound thereby, any Thing in the Constitution or Laws of any State to the Contrary notwithstanding.

U.S. ConsT. art. VI, cl. 2.

In deciding Testa, a decision based squarely on the supremacy clause, the Court relied heavily on its earlier interpretation of that clause in Claflin v. Houseman, 93 U.S. 130 (1876) (assignec in bankruptcy allowed to bring action in state court to recover from judgment suffered by bankrupt party which was obtained in violation of federal bankruptcy law). Although the question presented in Claflin was not whether a state court must entertain a federal cause of action, but rather whether it could do so, the Court's broad holding laid the foundation for the rule that state courts are obligated to entertain federal causes of action, a proposition later articulated explicitly in Testa. The Claflin Court declared:

[R]ights . . . acquired under the laws of the United States, may be prosecuted in the United States courts, or in the State courts, competent to decide rights of the like character and class .... The fact that a State court derives its existence and functions from the State laws is no reason why it should not afford relief; because it is subject also to the laws of the United States, and is just as much bound to recognize these as operative within the State as it is to recognize the State laws.

Id. at 136-37.

44. For a discussion of cases brought in state courts under the Federal Employers Liability Act, see Redish \& Muench, Adjudication of Federal Causes of Action in State Court, 75 MICH. L. REv. 311, 348-59 (1976).

45. 223 U.S. 1 (1912).

46. Id. at 57.

47. The Mondou Court stated:

The suggestion that the act of Congress is not in harmony with the policy of the State, and therefore that the courts of the State are free to decline jurisdiction, is quite inadmissible, because it presupposes what in legal contemplation does not exist. When Congress, in the exertion of the power confided to it by the Constitution, adopted that act, it spoke for all the people and all the States, and thereby established a policy for all. That policy is as much the policy of [the state] as if the act had emanated from its own legislature, and should be Id. respected accordingly in the courts of the State. 
fusion; but, be this as it may, it affords no reason for declining a jurisdiction conferred by law." ${ }^{38}$ In McKnett v. St. Louis \& San Francisco Railway, ${ }^{49}$ the Court reaffirmed the rule established in Mondou, and went on to announce that "[a] state may not discriminate against rights arising under federal laws." "so

Testa, Mondou, and McKnett firmly establish two principles: State courts are obligated to entertain federal causes of action whenever their jurisdiction is adequate to adjudicate similar claims, and state courts may not discriminate against federal causes of action. Under these rules, a state court may refuse to entertain a federal cause of action only if it has a neutral procedural or jurisdictional reason for so doing. ${ }^{51}$ To be neutral, a state court's reason for refusing to entertain a federal action must apply equally to all actions, whether provided by state or federal law.

\section{B. Section 1983 Actions in State Court}

Section 1983 claims should not be exempted from the requirement that Testa imposes on state courts to entertain federal causes of action. Although on two occasions the Supreme Court has specifically reserved the question whether state courts are required to entertain section 1983 actions, ${ }^{62}$ the Court has implied that they must. ${ }^{53}$ This Section will consider and reject two possible justifications for treating section 1983 claims dif-

48. Id. at 58. The Court has recently reaffirmed that Congress may place the burden of enforcing a federal law upon a branch of state government. See FERC v. Mississippi, 456 U.S. 742, 759-61 (1982). See generally Brilmayer \& Underhill, Congressional Obligation to Provide a Forum for Constitutional Claims: Discriminatory Jurisdictional Rules and the Conflict of Laws, 69 VA. L. REv. 819, 824-29, 838-40 (1983) (discussing duties of state courts in adjudicating federal claims).

49. 292 U.S. 230 (1934).

50. Id. at 234. See generally Solimine, Adjudication of Federal Civil Rights Actions in Ohio Courts, 9 U. DAyton L. REv. 39, 52-54 (1983) (discussing rule that state courts may not discriminate against federal causes of action).

51. For three cases in which the Supreme Court has held that the state was justified in refusing to entertain a federal cause of action due to a neutral procedural or jurisdictional rule, see Missouri ex rel. Southern Ry. v. Mayfield, 340 U.S. 1 (1950) (state court not prohibited from applying state forum non conveniens rule to federal causes of action); Herb v. Pitcairn, 324 U.S. 117 (1945) (state court's dismissal of federal cause of action held proper because action had been asserted in city court which had no jurisdiction over matter in question); Douglas v. New York, N.H. \& H.R.R., 279 U.S. 377 (1929) (upholding state court's dismissal of federal action pursuant to New York law denying non-residents right to sue foreign corporations in New York courts, because rule in question applied equally to both state and federal causes of action). For a discussion of these cases, see Redish \& Muench, supra note 44, at 352-54; Note, Amenability of States to Section 1983 Suits: Reexamining Quern v. Jordan, 62 B.U.L. REv. 731, 764-66 (1982).

52. The Court reserved the question in both Martinez v. California, 444 U.S. 277, 283 n.7 (1980), and Maine v. Thiboutot, 448 U.S. 1, 3 n.1 (1980). See supra note 37.

53. The language used in Martinez strongly implies that state courts must entertain $\S 1983$ actions: "We note that where the same type of claim, if arising under state law, would be enforced in the state courts, the state courts are generally not free to refuse enforcement of the federal claim." 444 U.S. at 283 n.7 (citing Testa, 330 U.S. at 394). 
ferently from other federal causes of action, and will conclude that state courts must entertain section 1983 claims.

\section{The "Mistrust" Justification}

At least one state court has asserted that it would be illogical to require state courts to entertain section 1983 actions in light of the fact that section 1983 was originally enacted precisely because Congress mistrusted these courts. ${ }^{54}$ Support for the propositions that the 1871 Congress, which enacted section 1983, was creating a cause of action in federal court and that the 1871 Congress would not have expected state courts to be required to entertain these claims can be mustered from portions of the legislative history of section $1983^{\mathrm{sS}}$ and from language in several Supreme Court decisions. ${ }^{56}$ When taken in proper context, however, none of these passages support the contention that state courts should be free to refuse to enforce section 1983. Indeed, other portions of the legislative history ${ }^{57}$ and other Supreme Court decisions examining that history ${ }^{68}$ suggest the opposite conclusion, that state courts are obligated to entertain section 1983 actions.

The broad purpose of section 1983 supports the proposition that state courts must entertain these claims. Section 1983 was enacted to ensure the protection of federal rights, ${ }^{59}$ and the provision of a federal forum was

54. See Chamberlain v. Brown, 223 Tenn. 25, 35, 442 S.W.2d 248, 252 (1969) ("II]t would be illogical indeed to hold that a State court should enforce, or is required to enforce, an alleged cause of action which owes its very existence to congressional recognition of reluctance or refusal of State Courts to act.").

55.

This section gives to any person who may have been injured in any of his rights, privileges, or immunities of person or property, a civil action for damages against the wrongdoer in the Federal courts . . . . It is a covert attempt to transfer another large portion of jurisdiction from the State tribunals, to which it of right belongs, to those of the United States.

Cong. Globe, 42nd Cong., 1st Sess., app. 50 (1871) (statement of Rep. Kerr discussing precursor of $\S 1983)$, reprinted in Monroe v. Pape, 365 U.S. 167, 178-79 (1961).

56. See, e.g., Mitchum v. Foster, 407 U.S. 225, 242 (1972) ("The very purpose of $\S 1983$ was to interpose the federal courts between the States and the people. . . "); Monroe v. Pape, 365 U.S. at 180 ("It is abundantly clear that one reason the legislation was passed was to afford a federal right in federal courts ....").

57.

I do not say that this section gives to the Federal courts exclusive jurisdiction. I do not suppose that it is so understood. It leaves it, I presume, in the option of the person who imagines himself to be injured to sue in the State court or in the Federal court . . . .

Cong. Globe, 42nd Cong., 1st Sess., app. 216 (1871) (statement of Sen. Thurman discussing precursor of $\$ 1983$ ), reprinted in Patsy v. Board of Regents, 457 U.S. 496,507 (1982).

58. See, e.g., Patsy, 457 U.S. at 506 ("[M]any legislarors interpreted [\$ 1983] to provide dual or concurrent forums in the state and federal system, enabling the plaintiff to choose the forum in which to seek relief."); Allen v. McCurry, 449 U.S. 90, 99 (1980) (By enacting $\$ 1983$, "Congress was adding to the jurisdiction of the federal courts, not subtracting from that of the state courts.").

59. State courts routinely adjudicate claims implicating federal rights. The typical criminal case almost always involves the protection of federal rights, and state judges routinely preside over these matters. Moreover, "[i]t denigrates the judges who serve on the state courts to suggest that they will 
only a means to achieve that end, not an end in itself. Ensuring a state court option only strengthens the commitment to protecting federal rights. The federal courts will, of course, continue to entertain section 1983 actions, ${ }^{60}$ but state courts will provide an alternative forum for those claimants who believe that state courts will better protect their federal rights. ${ }^{61}$

Testa imposes a duty on state courts to entertain federal causes of action. ${ }^{62}$ Although section 1983 is a remedial provision and creates no new rights, ${ }^{63}$ this characterization does not alter the duty of state courts. State courts are obligated under the supremacy clause to protect federal rights; the remedies under section 1983 and section $1988^{64}$ provide the means of ensuring that deprivations of federal rights do not go unvindicated. Allowing state courts to refuse to entertain section 1983 actions would "ratify adherence to the very evil the civil rights acts were designed to obviate-the refusal of state courts and officers to vindicate civil rights afforded by the Constitution of the United States."

\section{The "Optional Jurisdiction" Justification}

The jurisdictional grant for section 1983, 28 U.S.G. $\S 1343,{ }^{68}$ provides only for "original" jurisdiction for federal district courts and makes no

not enforce the supreme law of the land." Atascadero State Hosp. v. Scanlon, 105 S. Ct. 3142,3146 n.2 (1985). But see Neuborne, The Myth of Parity, 90 HARv. L. REv. 1105 (1977) (arguing that state courts are inferior at protecting federal rights).

60. There are, however, a number of cases $\rightarrow$ most notably state tax actions-in which the federal courts will not be available. See supra notes $14-34$ and accompanying text.

61. It would not be proper for a state court to refuse to entertain a $\S 1983$ action because the state court believed it would not protect the claimant's federal rights as well as a federal court. Rather, the claimant is the party most suited to choose the forum that will best protect his rights. The United States Supreme Court is of course available to monitor the holdings of state courts to ensure that these courts are properly protecting claimants' federal rights. See 28 U.S.C. $\$ 1257$ (1982).

62. 330 U.S. at 394.

63. See Chapman v. Houston Welfare Rights Org., 441 U.S. 600, 617-18 (1979).

64. When Congress enacted $\S 1988$, it was clear that the attorney's fees provided under that section would be available in state court. See Maine v. Thiboutot, 448 U.S. 1, 11 (1980). At that time, state courts were the only potential fora for certain $\S 1983$ actions because Congress had not removed the $\$ 10,000$ minimum amount in controversy requirement for federal court jurisdiction over federal claims, including those asserted under $\S 1983$. Id. at $11 \mathrm{n.12}$. If Congress intended $\S 1988$ to be applied consistently and to benefit those most in need of its protections-claimants with monetary disincentives to vindicating their federal rights-then it is logical to assume that Congress expected state courts to entertain actions involving $\S 1988$, such as those brought under $\S 1983$.

65. Terry v. Kolski, 78 Wis. $2 d$ 475, 489 n.2, 254 N.W.2d 704, 709 n.2 (1977).

66. See Lynch v. Household Finance Corp., 405 U.S. 538, 540, 545 (1972) (recognizing $§ 1343$ as jurisdictional grant for $\$ 1983$ claims challenging deprivations of constitutional rights). Section 1343 provides in pertinent part:

(a) The district courts shall have original jurisdiction of any civil action authorized by law

to be commenced by any person:

(3) To redress the deprivation, under color of any State law, statute, ordinance, regulation, custom or usage, of any right, privilege or immunity secured by the Constitution of the United States or by any Act of Congress providing for equal rights of citizens or of all persons within the jurisdiction of the United States . ... 
explicit reference to state courts. As a result, at least one commentator has suggested that although state courts may have jurisdiction over section 1983 actions, they may opt to refuse to exercise this jurisdiction. ${ }^{67}$ The supremacy clause and Mondou, however, counsel against such a conclusion. Under the supremacy clause, state judges are required to uphold the federal Constitution and federal laws. Section 1983 is such a law, encompassing both federal constitutional and statutory rights. Moreover, the Mondou Court stated that "[t]he existence of . . . jurisdiction creates an implication of duty to exercise it." ${ }^{\text {"8s }}$ State courts have jurisdiction over section 1983; ${ }^{69}$ the logic of Mondou therefore compels the conclusion that they must exercise it. ${ }^{70}$

The Supreme Court's decision in Sullivan v. Little Hunting Park also belies the contention that because section 1983's jurisdictional grant, section 1343, does not mention state courts, those courts are not required to entertain section 1983 actions. Sullivan involved an action brought in a Virginia state court under 42 U.S.C. $\$ 1982,{ }^{72}$ a federal law also having section 1343 as its jurisdictional provision. ${ }^{73}$ The Sullivan Court ruled that if the Virginia court's jurisdiction were adequate to hear similar state claims and to grant relief similar to that requested under section 1982,

28 U.S.C. $\S 1343$ (1982). For a discussion of $\S 1343$ as the jurisdictional grant for $\S 1983$ actions alleging a denial of federal statutory rights, see Chapman v. Houston Welfare Rights Org., 441 U.S. 600 .

67. See Sandalow, Henry v. Mississippi and the Adequate State Ground: Proposals for a Revised Doctrine, 1965 SuP. CT. REv. 187, 207 (requiring state courts to entertain federal causes of action places burden on these courts, and as such, "[i]n the absence of a declaration by Congress that state courts must enforce rights that Congress has created, there appears to be no substantial reason why the Supreme Court should impose such an obligation"). Contra Redish \& Muench, supra note 44, at 346-47; Note, suipra note 51, at 771-72. Although Dean Sandalow does not examine $\S 1983$ specifically, the cause of action provided by that section is paradigmatic of the congressionally-created rights of action he does examine.

68. 223 U.S. at 58. The Mondou Court made no reference to the source of jurisdiction; it referred only to its existence. Indeed, the Federal Employers Liability Act, the federal statute at issue in Mondou, did not originally mention whether state courts would have jurisdiction over matters arising under the Act. A subsequent amendment noted the concurrent jurisdiction of state courts, but the Supreme Court held that this amendment "instead of granting jurisdiction to the state courts, presupposes that they already possessed it [under the general federal question statute]." Id. at 56.

69. See supra note 36 and accompanying text.

70. If state courts were allowed to refuse to entertain a federal cause of action unless Congress specifically enlisted them for the enforcement of the action, those courts would be free to discriminate against federal causes of action by capriciously accepting or rejecting jurisdiction over them. Although such discrimination is proscribed by McKnett, 292 U.S. at 234 , congressional silence would be tantamount to a state court license to discriminate. Because Congress intends for the laws that it enacts to be enforced consistently, state courts should be given discretion to decide whether to entertain a federal cause of action only if Congress specifically provides for such discretion.

71. 396 U.S. 229 (1969).

72. Section 1982 provides:

All citizens of the United States shall have the same right, in every State and Territory, as is enjoyed by white citizens thereof to inherit, purchase, lease, sell, hold, and convey real and personal property.

42 U.S.C. \& 1982 (1982).

73. See Jones v. Alfred H. Mayer Co., 392 U.S. 409, 412 n.1 (1968). 
then that court could not refuse to entertain the claimant's section 1982 action. ${ }^{74}$ The Court so decided notwithstanding that section 1343 does not even mention state courts, much less specifically enlist their help.

\section{The Need for Access to State Courts Even When Federal Courts Are Available}

Although access to state courts is of particular importance to taxpayers asserting section 1983 actions because they are foreclosed from proceeding in federal courts, ${ }^{25}$ the availability of state courts is also important for other section 1983 claimants. Often, due to geographic, ${ }^{76}$ time, or financial constraints, ${ }^{77}$ a state court is the only practical forum available to a claimant asserting a section 1983 action. Moreover, because in some instances a state court will be the only forum having jurisdiction over the entire controversy and all parties involved, ${ }^{78}$ judicial economy can be served only if state courts are open to section 1983 claims.

\section{State Courts and State Tax Section 1983 Claims}

Despite their obligation to entertain section 1983 actions generally, most state courts have mistakenly refused to hear state tax section 1983 claims. ${ }^{29}$ After dispelling the broad notion that state courts may not enter-

74. "[Under \$ 1982] a federal court has power to fashion an effective equitable remedy.... That federal remedy for the protection of a federal right is available in the state court, if that court is empowered to grant injunctive relief generally ...." 396 U.S. at 238 (citation omitted); cf. Testa, 330 U.S. at 394 (state court must entertain federal cause of action if it has jurisdiction "adequate and appropriate under established local law" to adjudicate similar state law claims).

75. See supra notes 14-34 and accompanying text.

76. The availability of a state forum would be especially helpful for residents of the western states, where the nearest federal court might be hundreds of miles away but a state court would never be farther away than the county seat. See New Times, Inc. v. Arizona Bd. of Regents, 20 Ariz. App. 422, 427, 513 P.2d 960, 965 (1973) ("[M]any citizens of this state, because of their geographical residence, would be inconvenienced if they were forced to litigate in a federal, rather than a state, court."), vacated, 110 Ariz. 367, 519 P.2d 169 (1974).

77. While the delay is usually longer in state court than in federal court, $c f$. Neuborne, supra note 59, at 1122 (noting that most state courts have a larger caseload burden than their federal counterparts), the opposite is true in some jurisdictions. Telephone interview with Mary Elsner, Senior Research Associate, Center for State Courts (Mar. 4, 1985). Moreover, the expense of litigating a matter is usually higher in federal than state court. Id.

78. A federal court hearing a federal claim or a diversity claim does not have ancillary jurisdiction over a non-diverse party against whom a non-federal claim is being asserted, even if the claim arises out of the same nucleus of operative facts that generated the claim over which the court does have proper jurisdiction. See Owen Equipment \& Erection Co. v. Kroger, 437 U.S. 365 (1978). Thus, if a claimant has a $\S 1983$ action against one party and a state-provided cause of action against another non-diverse party, and both claims arise out of a common nucleus of operative facts, the federal court will not be able to entertain the second cause of action. See, e.g., Aldinger v. Howard, 427 U.S. 1 (1976). A state court would, however, be able to entertain both claims.

79. See Backus v. Chilivis, 236 Ga. 500, 505, 224 S.E.2d 370, 374 (1976) (taxpayer may not circumvent state procedures by asserting $\$ 1983$ claim); State Tax Comm'n v. Fondren, 387 So. 2d 712,723 (Miss. 1980) (en banc) (because state tax $\S 1983$ claim may not be litigated in federal court, it likewise may not be litigated in state court), cert. denied, 450 U.S. 1040 (1981); Stufflebaum v. 
tain state tax section 1983 actions for the same reasons that federal courts may not, Part III will rebut the other justifications proferred by state courts for refusing to hear these actions and will conclude that state courts must entertain state tax section 1983 claims. $^{80}$

\section{A. The Flaw in the Fondren Reasoning}

State taxation has always been an area in which the federal courts have granted great deference to the states and their courts, ${ }^{\mathbf{8 1}}$ but this policy of federal court noninterference with state taxation should not be confused with or subsumed within a policy of complete federal noninterference. In exercising their taxing power, the states must stay within the bounds of the federal Constitution, and Congress may enact laws such as section 1983 to ensure that the states do not overstep these limits.

In State Tax Commission v. Fondren, ${ }^{82}$ the Supreme Court of Mississippi was confronted with the question whether section 1983 provides a

Panethiere, 691 S.W.2d 271, 272 (Mo. 1985) (en banc) (state tax $\S 1983$ claim held improper because state law provided plain, adequate, and complete remedy and thus complied with requirements of McNary); Strain v. Baryla, No. TSB-H-84(44)S (N.Y. State Tax Comm'n June 1, 1984) (available on LEXIS, States library, NYtax file) (Tax Injunction Act bars courts, including state courts, from entertaining $\S 1983$ claims challenging state taxation); Johnston v. Gaston County, 71 N.C. App. 707, 712-13, 323 S.E.2d 381, 384 (1984) (state tax $\$ 1983$ claim held improper because state law provided plain, adequate, and complete remedy and thus complied with requirements of $M c N a r y)$, review denied, 313 N.C. 508, 329 S.E.2d, 392 (1985); Spencer v. South Carolina Tax Comm'n, 281 S.C. 492, 497, 316 S.E.2d 386, 388-89 (1984) (taxpayer may not circumvent state remedies by invoking $\S$ 1983), aff d by an equally divided Court, 105 S. Ct. 1859 (1985) (per curiam). But see Beverly Bank v. Board of Review, 117 Ill. App. 3d 656, 664-65, 453 N.E.2d 96, 102 (1983) (state court entertained state tax $\S 1983$ claim), cert. denied, 104 S. Ct. 2153 (1984); Dutoit v. Board of County Comm'rs, 233 Kan. 995, 1004-06, 667 P.2d 879, 888-90 (1983) (same); Holden Arboretum v. City of Kirkland, No. 9-224 (Ohio Ct. App. June 29, 1984) (available on LEXIS, States library, Ohio file) (same).

At least two state courts that have accepted jurisdiction over non-tax $\$ 1983$ claims have refused to entertain state tax $\S 1983$ actions. Compare Davis v. City of Roswell, 250 Ga. 8, 295 S.E.2d 317 (1982) (accepting jurisdiction over non-tax $\$ 1983$ claim) and Shapiro v. Columbia Union Nat'l Bank \& Trust Co., 576 S.W.2d 310 (Mo. 1978) (en banc) (same), cert. denied, 444 U.S. 831 (1979) with Backus v. Chilivis, $236 \mathrm{Ga}$. 500, 224 S.E.2d 370 (refusing to entertain taxpayer's $§ 1983$ claim) and Stufflebaum v. Panethicre, 691 S.W.2d 271 (same). The refusal in Backus may have been proper given that state courts may be allowed to require state tax $\$ 1983$ claimants to exhaust state-provided administrative remedies before asserting a $\S 1983$ claim. See infra note 94 . The Backus court, however, did not make clear whether it was relying on these grounds.

80. The Supreme Court granted certiorari and heard arguments in a case that presented the question whether state courts must entertain state tax $\S 1983$ claims. Spencer v. South Carolina Tax Comm'n, 105 S. Ct. 242 (1984). The Court, however, was equally divided and rendered no opinion in the case. 105 S. Ct. 1859 (1985) (per curiam) (affirming refusal by South Carolina court to entertain state tax $\$ 1983$ claim).

81. See Dows v. City of Chicago, 78 U.S. (11 Wall.) 108, 110 (1871) (discussing federal equity jurisdiction over state tax matters and stating: "It is upon taxation that the several States chiefly rely to obtain the means to carry on their respective governments, and it is of the utmost importance to all of them that the modes adopted to enforce the taxes levied should be interfered with as little as possible."); accord California v. Grace Brethren Church, 457 U.S. 393, 410 n.23 (1982) (discussing reluctance of federal courts to interfere with state taxation and repeating above language from Dows).

82. 387 So. 2d 712 (Miss. 1980) (en banc), cert. denied, 450 U.S. 1040 (1981). 
remedy for unconstitutional taxation. The court concluded: "[The state tax] section 1983 cause of action must fail in the state court because it would have failed if it had been filed . . . in federal court." Although the Fondren court correctly determined that a federal court could not have considered the state tax section 1983 claim, the court mistakenly conflated the unavailability of a federal forum into a broader unavailability of section 1983 as a remedy for unconstitutional taxation. ${ }^{84}$ The general policy of federal court noninterference with state taxation forecloses taxpayers from asserting section 1983 actions in federal court; it does not prevent them from pursuing these same remedies in state court. Neither the Eleventh Amendment, the Tax Injunction Act, nor the principle of comity affect the actionability of a state tax section 1983 claim in state court, nor do they imply any state immunity from federal interference with state taxation.

The Eleventh Amendment, by its plain language, only addresses the amenability of states to suits in federal court; it does not affect the amenability of states to actions-such as those brought under section 1983-that are asserted in state court. ${ }^{85}$ Likewise, the Tax Injunction Act does not bar taxpayers from pursuing federal remedies in state courts. ${ }^{86} \mathrm{By}$ its terms, the Act affects only the jurisdiction of the federal district courts. ${ }^{87}$ The Tax Injunction Act was passed to limit federal court interference

83. Id. at 723 .

84. In ruling that a state court need not entertain a state tax $\$ 1983$ claim, the Fondren court relied heavily on the Tax Injunction Act. For analytical purposes, however, this Note will evaluate a broader rationale implicit in Fondren: because state tax $\S 1983$ claims are not actionable in federal court, they may not be asserted in state court either.

85. See Maine v. Thiboutot, 448 U.S. 1, 9 n.7 (1980) ("No Eleventh Amendment question is present. . . where an action is brought in a state court since the Amendment, by its terms, restrains only "tt]he Judicial power of the United States." "); Employees of Dep't of Pub. Health \& Welfare v. Department of Pub. Health \& Welfare, 411 U.S. 279, 293-94 (1973) (Marshall, J., concurring) (discussing Eleventh Amendment and stating: "The issue is not the general immunity of the States from private suit-a question of the common law-but merely the susceptibility of the States to suit before federal tribunals.").

86. See Strain v. Baryla, No. TSB-H-84(44)S (N.Y. State Tax Comm'n June 1, 1984) (available on LEXIS, States library, NYtax file) (mistakenly relying on fact that Tax Injunction Act precludes federal courts from entertaining state tax $\S 1983$ claims in ruling that these claims cannot be pursued in state court).

87. The Tax Injunction Act was always referred to as a bill "to amend . . . the Judicial Code . . . with respect to the jurisdiction of the district courts of the United States over suits relating to the collection of State taxes." 81 CoNG. REc. 1271 (1937). The text of the Act, which refers only to the federal district courts, makes clear that it is merely a jurisdiction-shifting provision. See supra note 15. The legislative history and narrow focus of the Tax Injunction Act also make clear that the Act was not a congressional preemption of the remedies provided by $\S 1983$ in the area of state taxation. $C f$. Middlesex County Sewerage Auth. v. National Sea Clammers Ass'n, 453 U.S. 1 (1981) (comprehensive congressional remedial provision in particular field supplants $\S 1983$ in that area). 
with state taxation ${ }^{88}$ and merely transfers a class of claims, including federally-provided causes of action, from federal to state court. ${ }^{\mathbf{8}}$

A persuasive argument can be made that the Tax Injunction Act was enacted, at least in part, to protect state tax revenues by ensuring that individuals pay their taxes before litigating their controversy. ${ }^{90}$ Allowing state tax section 1983 claims, and indeed, requiring state courts to entertain them, arguably could undermine this goal. The argument is that because a section 1983 claimant is not generally required to exhaust his administrative remedies, ${ }^{91}$ that claimant can proceed directly to state court, and because the section 1983 action is a federal action, state requirements-such as the requirement that a claimant pay the tax prior to litigating his claim-would not control.

A state tax section 1983 cause of action will not, however, jeopardize the integrity of states' tax systems. In the first place, only a taxpayer deprived of a federal constitutional right ${ }^{92}$ will be able to assert a successful section 1983 action; most tax challenges lack this crucial element. ${ }^{93}$ Second, because the state tax section 1983 action lies in state court, rather than in federal court where no exhaustion is required, state courts may be able to require a taxpayer to exhaust state administrative remedies before

88. Congress enacted the Tax Injunction Act for three reasons. First, Congress wanted to curtail the federal district court's burgeoning practice of enjoining state tax collection. As a result of these injunctions, large corporations had often been able to withhold state taxes "in such vast amounts and for such long periods as to disrupt State and county finances, and thus make it possible for such corporations to determine for themselves the amount of taxes they [would] pay." 81 CoNG. REC. 1416 (1937) (remarks of Sen. Bone).

Second, Congress wanted to eliminate discrimination against residents of the state imposing the tax. As a result of federal diversity jurisdiction, non-resident citizens and corporations had a choice between state and federal court, but residents of the forum state were usually compelled to litigate their controversy in state court. $I d$. at 1416-17.

Third, Congress sought to return control over state tax matters to state courts. Id. There is, however, no evidence that Congress was attempting to free the states from the requirements of the Constitution and the laws enacted by Congress to protect constitutional rights.

89. "The Tax Injunction Act embodied Congress' decision to transfer jurisdiction over a class of substantive federal claims from the federal district courts to the state courts . . ." Rosewell v. LaSalle Nat'l Bank, 450 U.S. 503, 515 n.19 (1981); see also California v. Grace Brethren Church, 457 U.S. at 411 ("Congress' intent in enacting the Tax Injunction Act was to prevent federal-court interference with the assessment and collection of state taxes") (emphasis added).

90. See 81 Cong. Rec. 1415-17 (1937) (remarks of Sen. Bone).

91. See Patsy v. Board of Regents, 457 U.S. 496 (1982) (exhaustion of state administrative remedies not required before proceeding with $\S 1983$ action in federal court).

92. See, e.g., Shutt v. Moore, 26 Wash. App. 450, 453, 613 P.2d 1188, 1190 (1980) (conclusory allegations of violations of federal rights are not sufficient to state claim under $\S 1983$; rather, "plaintiff must allege facts establishing that specific constitutional rights have been violated").

93. A taxpayer claiming that he was mistakenly overtaxed-and thus, deprived of his property without due process-will not be allowed to bring a $\$ 1983$ action prior to the exhaustion of his stateprovided administrative and judicial remedies. See Parratt v. Taylor, 451 U.S. 527 (1981) (establishing exhaustion-like requirement for claimants asserting due process $\$ 1983$ actions); see also $405 \mathrm{Co}$. v. State, 118 Misc. 2d 305, 308-09, 460 N.Y.S.2d 455, 458 (Ct. Cl. 1983) (taxpayer's $\S 1983$ claim alleging due process violation held improper because taxpayer had adequate remedy under state law). 


\section{asserting his section 1983 action. $^{94}$ Finally, even if he is litigating a sub-}

94. Although Patsy v. Board of Regents, 457 U.S. 496, established that a claimant need not exhaust state administrative remedies before asserting a $\S 1983$ claim in federal court, it is not clear whether this rule is also applicable if the $\$ 1983$ action is asserted in state court. See Note, Exhaustion of Administrative Remedies in Section 1983 Actions Brought in State Court, 69 lowA L. REv. 1037, 1042-44 (1984) [hereinafter cited as Note, Exhaustion of Remedies]. Several state courts have ruled that Patsy is not applicable to $\S 1983$ actions in state court and that a $\S 1983$ claimant proceeding in state court must exhaust his state administrative remedies. See, e.g., Bartschi v. Chico Community Memorial Hosp., 137 Cal. App. 3d 502, 508, 187 Cal. Rptr. 61, 64-65 (3d Dist. 1982) (requiring $\$ 1983$ claimant in state court to exhaust administrative remedies); State ex rel. Basham v. Medical Licensing Bd., 451 N.E.2d 691, 694 (Ind. Ct. App. 1983) (same). But see, e.g., Logan v. Southern Cal. Rapid Transit Dist., 136 Cal. App. 3d 116, 124, 185 Cal. Rptr. 878, 883 (2d Dist. 1982) (not requiring $\$ 1983$ claimant in state court to exhaust administrative remedies); Fetterman v. University of Conn., 192 Conn. 539, 549, 473 A.2d 1176, 1181 (1984) (same).

State courts entertaining federal causes of action control their own procedure, see C. WRIGHT, THE LAw of Federal. CourTs 272 (4th ed. 1983), and requiring exhaustion of administrative remedies can be viewed as a procedural requirement, see Note, Exhaustion of Remedies, supra, at 1044-53. Although Congress can probably prescribe the procedural rules that a state court adjudicating a fedcral cause of action must follow, see C. WRIGHT, supra, at 272, it appears that Congress did not intend to alter state exhaustion requirements when a $\$ 1983$ claim is instituted in state court. In ruling that claimants asserting $\S 1983$ actions in federał court need not exhaust state administrative remedies, the Patsy Court was informed by three recurring themes in the congressional debates over $\S 1983$. Congress wanted to ensure that $\S 1983$ claimants had immediate access to federal courts, an independent federal fact finder, and an unimpaired choice between federal and state court. 457 U.S. at 503-07. None of these considerations is implicated, however, when the claimant asserts his § 1983 action in state court. Moreover, there are compelling reasons why a state should be allowed to have a limited exhaustion requirement, especially in the area of state taxation. Such a requirement would provide the state an opportunity to correct errors before resorting to costly litigation and would foster "agency expertise, judicial economy . . . and consistent application of a regulatory scheme." Note, Fulton Market Cold Storage Co. v. Cullerton: Limiting Federal Jurisdiction in Section 1983 Damage Actions Against Tax Officials, 74 Nw. U.L. REv. 284, 306 \& n.120 (1979) [hereinafter cited as Note, Limiting Federal Jurisdiction].

A state cannot, however, establish an administrative exhaustion requirement so onerous that a taxpayer would prefer to forgo his $\S 1983$ claim rather than incur the expense and trouble of meeting the state's "procedural" requirement. It is settled that a state may not, under the guise of state procedure, place obstacles in the path of a federal claimant that defeat his federal rights. See Davis v. Wechsler, 263 U.S. 22, 24-25 (1923). Moreover, an exhaustion requirement for $\S 1983$ actions would have to apply equally to any state-provided taxpayer remedies. See McKnett, 292 U.S. at 234 (prohibiting discrimination against federal causes of action). If the state's exhaustion requirement were sufficiently onerous to dissuade a taxpayer from seeking the remedies under $\S 1983$, it would similarly discourage the taxpayer from seeking state-provided remedies. Given these circumstances, the taxpayer's state court remedies-those provided by the state and those under $\$ 1983$-would be illusory and therefore would not comply with the requirements of the Tax Injunction Act, see supra note 15 (remedy must be "plain, speedy and efficient"), or the principle of comity as articulated by the Court in McNary, 454 U.S. at 116 (remedy must be "plain, adequate, and complete"). Under the Tax Injunction Act and McNary, therefore, a taxpayer facing such an exhaustion requirement would be granted access to a federal forum in which he could assert a $\S 1983$ action. This solution suffers in that taxpayers are forced to assess whether a federal court will find the state court remedy inadequate, but it does ensure that a state will not ultimately be able to circumvent $\$ 1983$ with "procedural" requirements. Moreover, it is possible that an extensive and vexing exhaustion requirement would not comport with the requirements of the Fourteenth Amendment. See, e.g., Ward v. Board of County Comm'rs, 253 U.S. 17 (1920) (taxpayer must have opportunity to challenge unconstitutional state taxation).

Although a state may be allowed to require exhaustion of state administrative remedies, the need to ensure the protection of federal rights and the desire to promote judicial economy militate against allowing a state to require $\S 1983$ claimants to exhaust state judicial remedies before proceeding with their $§ 1983$ claims. See Note, Limiting Federal Jurisdiction, supra, at 307 \& n.125; cf. McNary, 454 U.S. at 134 n.22 (Brennan, J., concurring) (arguing that state tax $\S 1983$ claimants should not be able to proceed in federal court until they have exhausted their state administrative remedies, but noting that exhaustion of judicial remedies would not be required). 
stantial federal claim, a state tax section 1983 claimant will not be exempted from paying the tax he owes. Section 1983 neither alters the requirements necessary to obtain equitable relief nor prevents a state from enforcing its laws. ${ }^{95}$ Therefore, a taxpayer cannot, by asserting a section 1983 cause of action, prevent a state from taking its usual steps to collect the taxes which it has levied.

Finally, the decision in McNary, which relied on comity to close the federal courts to certain state tax section 1983 claims, is not indicative of any belief that state tax section 1983 actions are themselves improper; the decision merely reflected the belief that these actions are more appropriately handled by state courts. In fact, the McNary Court stated that section 1983 does provide a remedy for taxpayers who are able to prove that their constitutional or federal rights have been denied by a state. ${ }^{98}$ The Court, through Justice Rehnquist, indicated that the taxpayers in $\mathrm{Mc}$ Nary were free to pursue their federal rights and remedies, including their section 1983 claim, in state court. $^{97}$

\section{B. The Proper Defendant in a State Tax Section 1983 Suit}

A taxpayer may bring a state tax section 1983 claim against a state official in her individual capacity, against a state official in her official capacity, or against a state. A suit against an official, such as a tax assessor, in her individual capacity is appropriate when the taxpayer is alleging that the official's discretionary acts-such as overassessing the property of nonresidents-led to the deprivation of the taxpayer's constitutional rights. ${ }^{98}$ In an individual-capacity suit, the official is personally

95. The fact that a $\S 1983$ claim is being litigated does not in any way prevent the state from taxing the claimant and using the normal methods of ensuring that the tax is paid. Only if the taxpayer is granted an injunction or a declaratory judgment would a state officer face sanctions for enforcing a tax law. The availability of a $\$ 1983$ cause of action will not, however, aid taxpayers in restraining tax enforcement because $\S 1983$ does not alter the normal considerations that a court of equity faces. See, e.g., Allee v. Medrano, 416 U.S. 802, 814 (1974) (plaintiff required to prove same elements to obtain injunctive relief irrespective of whether such relief is sought under $\$ 1983$ ); see also Rizzo v. Goode, 423 U.S. 362, 378 (1976) (injunctive relief in $\S 1983$ actions should be granted "sparingly"). If an adequate remedy exists at law, equitable relief-in the form of an injunction or a declaratory judgment - will not be granted. See Scott v. Palmerton Area School Dist., 63 Pa. Commw. $528,533-34,439$ A.2d 859, 862 (1981) (although \$ 1983 authorizes equitable remedy, such relief will not be granted if adequate remedy exists at law), affd, $502 \mathrm{~Pa} .431,466 \mathrm{~A} .2 \mathrm{~d} 1029$ (1983).

96. 454 U.S. at 103-04.

97. Id. at 116. See also Pennhurst State School \& Hosp. v. Halderman, 465 U.S. 89, 122 (1984) (discussing state tax $\S 1983$ actions). Given that the federal courts are not available to hear state tax $\S 1983$ claims, the Supreme Court's references to such claims suggest that state courts must entertain these actions. The Pennhurst Court specifically noted that state courts are the only potential fora for these claims. $I d$.

98. See Kentucky v. Graham, 105 S. Ct. 3099, 3106 (1985). The defendant official in this type of suit would presumably be permitted to raise a qualified immunity defense if her actions did not violate a clearly established constitutional right. See Harlow v. Fitzgerald, 457 U.S. 800, 818 (1982). 


\section{liable for both damages and any award of attorney's fees. ${ }^{99} \mathrm{~A}$ suit against a state ${ }^{100}$ or a state official in her official capacity ${ }^{\mathbf{1 0 1}}$ is appropriate when}

99. See Kentucky v. Graham, $105 \mathrm{~S}$. Ct. at 3106. For a discussion of whether a state may grant its officials absolute immunity from suit in state court, see infra note 101.

100. Although the Supreme Court has yet to consider the question, several lower courts have ruled that states are not subject to suit under $\S 1983$ because a state is not a "person" as that term is used in § 1983. See, e.g., Holladay v. Montana, 506 F. Supp. 1317, 1321 (D. Mont. 1981); Thompson v. New York, 487 F. Supp. 212, 226 (N.D.N.Y. 1979); cf. Quern v. Jordan, 440 U.S. 332 (1979) (§ 1983 does not abrogate states' Eleventh Amendment immunity from suit in federal court). But see Marrapese v. Rhode Island, 500 F. Supp. 1207, 1212 (D.R.I. 1980) (finding that state is "person" subject to suit under § 1983). For a thorough discussion of whether a state is a "person," see Note, supra note 51 (arguing that state is "person"). Even if a state is not a "person" under $\S 1983$, a taxpayer can still obtain redress by bringing a suit against an official in her official capacity. The Supreme Court in Hutto v. Finney, 437 U.S. 678 (1978) (suit for injunctive relief under $§ 1983$ against official in official capacity) made clear that an official sued in her official capacity is a "person" under § 1983. For a general discussion of the immunity of a state from suit in its own courts, see Wolcher, Sovereign Immunity and the Supremacy Clause: Damages Against States in Their Own Courts for Constitutional Violations, 69 CALrF. L. REv. 189 (1981).

101. A suit against an official in her official capacity could take two forms. First, the taxpayer could sue the official for damages under $\S 1983$, and if successful, the taxpayer would recover damages under $\S 1983$ and attorney's fees under $\S 1988$. Because the taxpayer sued the official in her official capacity, the state would be financially responsible for the claimant's judgment. See Hutto v. Finney, 437 U.S. at 694-98 (allowing attorney's fees to be collected from state in suit against official in official capacity notwithstanding state's immunity from such suit). If, however, an official-capacity damages action under $\S 1983$ were improper for some reason, then the taxpayer could seek injunctive or declaratory relief under $\S 1983$ against the official, and invoke state-provided remedies to recover any unconstitutionally collected taxes. If the taxpayer were successful, he could recover the improper tax and collect attorney's fees from the state under \$ 1988. See id.; of. New York Gaslight Club, Inc. v. Carey, 447 U.S. 54 (1980) (allowing successful claimant in Title VII suit to recover all attorney's fees incurred, including those incurred to comply with administrative remedy exhaustion requirement).

To prevent taxpayers from obtaining redress under $\S 1983$ in a suit against an official in her official capacity, a state might attempt to grant its officials immunity from suit in state court. If states are not directly subject to suits under $\S 1983$, see supra note 100 , such a grant of immunity to an official would effectively foreclose a taxpayer from pursuing the remedies provided by $\S 1983$. $C f$. supra note 33 (discussing whether state remedies are "adequate" if they do not include opportunity to recover remedies provided by $\S \S 1983$ and 1988). In an official-capacity suit, however, the taxpayer is essentially challenging a wrong committed not by an official but by the state itself. The broad purpose underlying $\S 1983$ counsels against allowing a state to foreclose a taxpayer from asserting an otherwise valid cause of action created by Congress to remedy the state's wrong. Cf. General Oil Co. v. Crain, 209 U.S. 211, 226 (1908) (if Eleventh Amendment precludes suit in federal court and state could forbid suit in state court, state could prevent enforcement of Constitution).

That states may not deny taxpayers the remedies provided under $\S 1983$ by granting immunity to officals is also supported by the converse of the Erie doctrine. For a general discussion of converseErie, see Hill, Substance and Procedure in State FELA Actions-The Converse of the Erie Problemi, 17 Онго ST. L.J. 384 (1956). Under converse-Erie, state courts entertaining federal causes of action must apply federal substantive law, but may apply state procedural law. See C. WRIGHT, supra note 94, at 272; $c f$. Minneapolis \& St. L. R.R. v. Bombolis, 241 U.S. 211 (1916) (state court hearing federal cause of action need not apply federal procedural law because court continues to draw its jurisdictional power from state). Because the immunity issue directly affects the outcome of the suit, and thus the federal policy underlying $\S 1983$, the question of immunity is most properly characterized as a question of federal substantive law and not as a matter of procedure within the control of the state creating the forum. Cf. Dice v. Akron, C. \& Y.R.R., 342 U.S. 359, 363 (1952) ("[T]he right to trial by jury is too substantial a part of the rights accorded by the [Federal Employers Liability Act]" to be denied by conflicting state procedural rules.). Moreover, any claim that the question of immunity is one for the sovereign empowering the official-in this case, the state-would have little merit. If the state, merely because it empowered the official, were permitted to exercise control over official immunity in a federal cause of action in state court, the state would be able to clothe that 
the taxpayer is alleging that a state statute, policy, or procedure is unconstitutional, either facially or as applied. Whether such an action is asserted against a state or an official in her official capacity, the state is responsible for any damages or attorney's fees awarded. ${ }^{\mathbf{1 0 2}}$

\section{The Impropriety of State Court Refusals: A Misunderstanding of Federalism}

State courts that have refused to adjudicate section 1983 tax claims have relied upon a broad theory of state immunity from the application of section 1983 in the area of state taxation that both disregards the nature of the relationship between the states and the federal government and is wholly at odds with the basic policy underlying section 1983 . For example, states have asserted that "[s]tate remedies . . . may not be circumvented by invoking section 1983."103 This assertion, however, is inconsistent with the Supreme Court's holding in Monroe v. Pape $e^{104}$ that the remedies provided under section 1983 are supplemental to any available state remedies. ${ }^{105}$ Accordingly, the remedies provided by section 1983, including attorney's fees under section 1988, are available in addition to state-provided remedies. ${ }^{108}$ That the remedies provided by section 1983 may conflict with state tax policy ${ }^{107}$ is similarly not a valid justification for a state court's refusing to entertain actions brought under that section. In enacting a law such as section 1983, Congress preempts conflicting state policy. ${ }^{108}$

Every state court that has refused to entertain a taxpayer's section 1983 claim has gone on to accept jurisdiction over any tax action provided by state law. ${ }^{109}$ This practice plainly discriminates against federal causes of

official with immunity from suit in federal court as well. At present, no state has attempted to grant such immunity, most likely because such a grant would not be respected by the federal courts. To allow the state this power would be to allow the states to control the scope of $\S 1983$, a clearly unacceptable result.

102. See supra note 101 .

103. Spencer v. South Carolina Tax Comm'n, 281 S.C. 492, 497, 316 S.E.2d 386, 389 (1984), affd by an equally divided Court, 105 S. Ct. 1859 (1985) (per curiam).

104. 365 U.S. 167 (1961).

105. Id. at 183 .

106. See Stratos v. Department of Pub. Welfare, 387 Mass. 312, 317, 439 N.E.2d 778, 783 (1982) ("T T]he fact that a plaintiff claiming relief under $\$ 1983$ could have obtained relief solely by means of a State remedy-even a 'routine' one-does not foreclose a fee award."). The holding in Monroe v. Pape and the logic of Stratos reveal the impropriety of the decision in Stufflebaum v. Panethiere, 691 S.W.2d 271 (Mo. 1985) (en banc), which held that a state court need not entertain a state tax $\$ 1983$ action if the taxpayer's state-provided remedies were plain, adequate, and complete as required by McNary. Stufflebaum, 691 S.W.2d at 272.

107. Cf. Backus v. Chilivis, $236 \mathrm{Ga} .500,505-06,224$ S.E.2d 370, 374-75 (1976) (discussing policy rationale underlying remedies provided by state for improper taxation and ruling that state court need not entertain state tax $\S 1983$ claim).

108. See Mondou, 223 U.S. at 57.

109. See cases cited supra note 79. 
action, and is therefore prohibited by $M c K n e t t .{ }^{110}$ Moreover, by entertaining state-provided causes of action, these courts have in effect admitted that they "have jurisdiction adequate and appropriate under local law" to adjudicate state tax section 1983 suits, and therefore they must comply with Testa's requirement that state courts entertain federal causes of action. ${ }^{111}$

\section{CONCLUSION}

Given that state courts are the only fora in which a taxpayer may seek federal remedies, including attorney's fees, and that these remedies are needed to protect citizens from unconstitutional taxation, it follows that state courts should not be free to close their doors to taxpayers with section 1983 claims. ${ }^{112}$ To allow state courts discretion to decide whether to entertain state tax section 1983 claims, is to make the vindication of federal rights dependent on the state in which a taxpayer resides. ${ }^{113}$ Short of opening the doors of the federal courts to state tax section 1983 claims-something that the Supreme Court has refused to allow-the only means available of ensuring consistent protection of federal rights for all taxpayers is to require state courts to entertain these claims.

110. 292 U.S. at 23 .

111. 330 U.S. at 394 . No state court that has refused to entertain a state tax $\S 1983$ claim has addressed whether such a refusal implicates Testa. See cases cited supra note 79.

112. See Gordon \& Gross, Justiciability of Federal Claims in State Court, 59 NoTRE DAME L. REv. 1145, 1189 (1984) ("If . . . Congress were to restrict inferior federal court jurisdiction so that federal claims had to be brought in state court, then state courts would have to provide the exact remedy required by federal law.").

113. Although the exact procedure under which a taxpayer's federal claim would be heard might vary from state to state, see supra note 94, every taxpayer, irrespective of the state in which he lived, would have the opportunity to assert a federal claim. See Gordon \& Gross, supra note 112, at 1163-65 \& nn.76-77 (all states have courts of general jurisdiction that are available to entertain $\S 1983$ claims). 
